\title{
Impact of Pesticide Contamination on Aquatic Microorganism Populations in the Littoral Zone
}

\author{
S. Lew $\cdot$ M. Lew $\cdot$ A. Biedunkiewicz \\ J. Szarek
}

Received: 19 September 2011/ Accepted: 19 November 2012/Published online: 11 December 2012

(C) The Author(s) 2012. This article is published with open access at Springerlink.com

\begin{abstract}
The effect of pesticide contamination of the littoral zone on the population of bacteria and fungi was analyzed using the example of a eutrophic water reservoir exposed for $>30$ years to the influence of expired cropprotection chemicals, mainly DDT. For three consecutive years, quantity analyses of bacteria and fungi were conducted and the composition of the microorganism population analyzed against seasonal dynamics. Mold and yeast-like fungi were also isolated and identified. Within the Bacteria domain, in addition to the large groups of microorganisms (Alphaprotobacteria, Betaprobacteria, and Gammaproteobacteria, Actinobacteria, and CytophagaFlavobacterium), the analysis also involved the presence of bacteria predisposed to degraded pesticides in natural environments: Pseudomonas spp. and Alcaligenes spp. The quantity dynamics of aquatic microorganisms indicated that bacteria and fungi under the influence of long-term exposure to DDT can adapt to the presence of this pesticide in water. No modifying effect of DDT was observed on the quantity of microorganisms or the pattern of seasonal relationships in the eutrophic lake. Changes were shown in the percentage share of large groups of bacteria in the community of microorganisms as was an effect of contamination on the species diversity of fungi. The data show the effectiveness of aquatic microorganism-community analyses as a tool for indicating changes in the water environment caused by pesticide contamination.
\end{abstract}

S. Lew $(\bowtie) \cdot$ A. Biedunkiewicz

Faculty of Biology and Biotechnology, University of Warmia and Mazury in Olsztyn, Oczapowskiego 1A, Olsztyn, Poland e-mail: sylwia.lew@uwm.edu.pl

M. Lew · J. Szarek

Faculty of Veterinary Medicine, University of Warmia and

Mazury in Olsztyn, Oczapowskiego 2, Olsztyn, Poland
Pesticide presence in natural ecosystems results from wide application in contemporary agriculture systems, application over many years, and the storage of pesticides past their expiration date in disposal sites unsuitable for this purpose (Carabias-Martinez et al. 2003; Cerejeira et al. 2003; Konstantinou et al. 2006; Hildenbrandt et al. 2008; Foit et al. 2010). Some of these preparations, currently withdrawn from use, are listed as persistent organic pollutants (POPs). The danger they pose results both from their acute toxicity and durability in the natural environment (Benimeli et al. 2003).

In ecosystems with an established presence of hazardous substances of anthropogenic origin, multidirectional and long-term (related to accumulation phenomenon) effects of pesticides have been observed (Fleeger et al. 2003; Manadori et al. 2006; Singh 2009; Skibniewska 2010). They affect organisms living in the natural environment, including those that are not their immediate target, which can consequently lead to changes in the quality and quantity composition of a population. Natural populations exhibit a number of responses to these contaminants, and the quickest reaction has been observed from microorganisms at the base of the trophic cascade: bacteria and fungi (DeLorenzo et al. 2001; Lew et al. 2011; Foit et al. 2010). These organisms can make use of substances entering the environment as feeding substrate for a source of energy or a building material, thus affecting balance in the ecosystem (Buesing and Gesser 2006). They are highly efficient in transforming organic pollutants entering their environment. They modify the structure of these compounds and their toxic properties, in many cases leading to complete mineralization of organic components into inorganic products (Zipper et al. 1996; Kalwasińska et al. 2010). 
The littoral zone is a transit zone between the terrestrial and aquatic environment. It is a biodiversity hot spot and home to many aquatic and terrestrial bacteria and fungi as well as a place where many energy-transformation processes take place (Wu et al. 2010). With macrophytes covering it and plants growing in this area, as well as microorganisms dwelling in open waters, this zone acts as a kind of filter protecting the ecosystem against harmful substances (Glinska-Lewczuk et al. 2009; Obolewski et al. 2009). A high concentration of organic substances and generally good thermal-aerobic conditions make this zone a place where autotrophic and heterotrophic bacteria and fungi can flourish (Kalwasińska et al. 2010). As a result of interest in this zone and its communities, many studies have focused on evaluating microbiological responses to exposure to various pesticides (DeLorenzo et al. 2001; Fleeger et al. 2003; Foit et al. 2010). However, the number of publications describing the reactions of bacteria and fungi to these substances in natural ecosystems is limited (Pesce et al. 2008; Leboulanger et al. 2011; Lew et al. 2011). This scarcity of studies has led us to pursue further research to understand how microorganisms in water ecosystems react to these POP exposures.

The subject of present work, therefore, was assessing the effect of chloro-organic pesticide DDT - a pesticide that has generally been withdrawn from use but persists in the environment - on the composition quality and quantity of bacteria and fungi in the water ecosystem. The aim of the research was to establish effects after many years of surface runoff into the lake from a nearby hazardous substance disposal site on the community of bacteria and fungi in the littoral zone of the water reservoir.

\section{Materials and Methods}

\section{Study Site and Sampling}

Sites located in the littoral zones of lakes Szeląg Wielki (Lit-1 exposed site and Lit-2 unexposed sites) and Ruda Woda (Lit-control) were selected for the research. These reservoirs are characterized by similar morphometric parameters (Table 1) in being eutrophic-type finger lakes. The lakes feature a poorly developed coastline with narrow littoral zones that do not exceed $15 \%$ of the lake area. Phytolittoral is composed here of plants of the Potamogetonetea class and the class of Phragmitetea, which is a characteristic community for eutrophic lakes (Grzybowski et al. 2005). They are situated in northeastern Poland, surrounded by forest complexes, and separated by a distance of $50 \mathrm{~km}$. A reclaimed area after pesticide-tomb liquidation in 2004 is situated in the direct drainage area of Lake Szeląg Wielki in the vicinity of the littoral zone (Lit-1
Table 1 Morphometric data of the water of lakes Szelagg Wielki and Ruda Woda

\begin{tabular}{lll}
\hline Morphometric date/lake & Szeląg Wielki & Ruda Woda \\
\hline Area (ha) & 599.0 & 654.1 \\
Volume $\times 10^{3}\left(\mathrm{~m}^{3}\right)$ & $81,111.2$ & $69,324.0$ \\
Maximal depth $(\mathrm{m})$ & 35.5 & 27.8 \\
Mean depth $(\mathrm{m})$ & 13.5 & 10.6 \\
Maximal length (m) & 12,500 & 12,050 \\
Maximal width (m) & 900 & 1750 \\
\hline
\end{tabular}

exposed site) on a sandy hill (104 m above sea level). This disposal site of plant-protection chemicals past their expiration date (mainly DDT) existed for 30 years and could hold $78 \mathrm{Mg}$ pesticides; however, at the moment of extraction, it contained $54 \mathrm{Mg}$ pesticides. From here, as a result of washing and erosion of soil from the area left after the pesticide dump, pesticides reached the water reservoir with rainfall as well as with a small stream flowing through this area and carrying water to Lake Szeląg Wielki, thus affecting the organisms inhabiting the lake, including bacteria and fungi (Grzybowski et al. 2005; Lew et al. 2011). The Lit-2 unexposed site is located in the opposite direction of the Lit-1 exposed site. No pesticide dump or area reclaimed after a pesticide-tomb release has been located in the vicinity of Lake Ruda Woda, and the littoral site (Lit-control) at this reservoir provided a control sample for our studies.

Water samples from the littoral zones of the lakes were collected from spring 2008 to autumn 2010 at 2 month intervals. Samples were collected from the subsurface layer -0.15 to $0.25 \mathrm{~m}$ from two sites on Lake Szeląg Wielki ([1] the littoral zone reached by the stream flowing from the reclaimed area [Lit-1 exposed site] and [2] the littoral zone on the opposite side of the lake [Lit-2 unexposed site]) as well as one littoral site on Lake Ruda Woda (Lit-control).

\section{Hydrochemical Parameters}

Selected hydrochemical parameters were measured along with a collection of microbiological samples. A multiparameter water-quality meter YSI 6600 (Xylem Inc., Yellow Springs, USA) was used to determine temperature $\left(\mathrm{T}{ }^{\circ} \mathrm{C}\right)$, dissolved oxygen ( $\mathrm{DO} \mu \mathrm{g}_{*} 1^{-1}$ ), and $\mathrm{pH}$. The content of DDT and its metabolites (DDE, DDD, and DDT) was determined with the method proposed by Amarowicz et al. (1986) using a PU 4600 gas chromatograph and by Ludwicki et al. (1996) in a modified version adapted for water analyses. The accuracy of measurements of chloroorganic insecticides in water was calculated with the formula $\mathrm{W}=[(\mathrm{a}-\mathrm{b}) / \mathrm{c}] \times 100$, where $\mathrm{W}$ denotes the recovery coefficient expressed as a percentage value, a indicates the 
amount of standard determined in an enriched sample, $b$ stands for the amount of standard determined in a blind sample, whereas c denotes the added amount.

\section{Total Bacterial Abundance}

Bacterial abundance was determined by epifluorescence microscopy (Porter and Feig 1980). Triplicate subsamples were fixed with neutralized formaldehyde ( $\mathrm{pH} 7.4$; final concentration $4 \%$ ) and stained with DAPI (Sigma-Aldrich, St. Louis, MO, USA) final concentration $0.01 \mu \mathrm{g} \mathrm{mL}{ }^{-1}$ for $15 \mathrm{~min}$ in the dark. The samples were then filtered gently through $0.2-\mu \mathrm{m}$ black Nuclepore filters (type GTTP; Millipore). Bacteria were counted under an Olympus epifluorescence microscope. More than 1000 bacterial cells in 20 objective fields were counted.

\section{Total Fungal Abundance}

To determine the number of fungi colonies, the method of membrane filters was used (Qureshi and Dutka 1976; Biedunkiewicz and Baranowska 2011). A total of $500 \mathrm{~mL}$ water was filtered through a membrane filter (FMW-5/50), placed on dishes with solid Sabouraud's medium, and incubated for 48 to $72 \mathrm{~h}$ at $37{ }^{\circ} \mathrm{C}$. Afterward, yeast fungi colonies were counted, sieved onto Sabouraud's agar slant with chloramphenicol, and then incubated again at $37{ }^{\circ} \mathrm{C}$ for 48 to $72 \mathrm{~h}$. The analysis was performed in three replications for each site and for all collection points of littoral water samples (Biedunkiewicz-Ziomek and Dynowska 2004).

\section{Microorganisms of Littoral Zone Composition}

\section{Bacteria}

Samples for community analysis were fixed in freshly buffered prepared paraformaldehyde $(\mathrm{pH}$ 7.4) to a final concentration of $2 \%$ (vol/vol) and stored for several hours at $4{ }^{\circ} \mathrm{C}$. The samples were filtered through white polycarbonate filters (type GTTP; Millipore), rinsed twice with sterile water, dried at room temperature, and stored at $-20{ }^{\circ} \mathrm{C}$. Bacterial community composition was investigated by fluorescent in situ hybridization (FISH) with the use of Cy3-labeled oligonucleotide probes in accordance with the hybridization procedure for aquatic microorganisms proposed by Pernthaler et al. (2001a, b). The rRNAtargeted oligonucleotide probes were used to detect bacteria of the ALF 968, -BET42a, and GAM42a subdivisions of Proteobacteria and of the Cytophaga-Flavobacterium cluster CF319a (Manz et al. 1992). Gram-positive bacteria with a high concentration of GC-Actinobacteria were identified using an HGC 69a probe (Roller et al. 1994). To determine the proper bacteria belonging to the
Eubacteria group, an EUB 338 I-III $_{\text {probe was used (Daims }}$ et al. 1999). To detect microorganisms capable of decomposing pesticides (mainly DDT), a PAE 997 probe was chosen for Pseudomonas spp. and an ALBO 557 for Alcaligenes spp. (Friberg-Jansen et al. 2003).

Bacterial cells on the filter sections were observed with an epifluorescent microscope equipped with filter sets for DAPI and Cy3. The fractions of FISH-stained bacteria in at least 1000 DAPI-stained cells/sample were quantified.

\section{Fungi}

Diagnostics for yeast-like fungi were performed on the basis of morphological and biochemical features (zymograms and auxanograms). The macroscopic assessment was performed on the basis of features of the colonies developed, and microscopic characteristics of fungi were examined in in vivo preparations in a drop of water dyed with methylene blue and in microcultures incubated for 48 , 72, and $144 \mathrm{~h}$ (Biedunkiewicz-Ziomek and Dynowska 2004) at $37{ }^{\circ} \mathrm{C}$ on Nickerson substrate. Colonies of mold fungi from the Sabouraud's substratum were sieved onto dishes with a Czapek-Dox substrate. Preparations were produced from the fungi obtained, applying the imprinting method with the use of adhesive tape, and dyed with methylene blue with lactophenol according to Gerlach (1972). Mold fungi were identified on the basis of the morphology and macroscopic features of the mycelium formed (De Hoog et al. 2000; Howard 2003; Kurtzmann and Fell 2000; Lodder and Kreger-van Rij 1967; Midgley et al. 1997; Raper and Fennel 1965; Raper et al. 1949).

\section{Data Analyses}

Samples from the lakes were taken in triplicate to determine the variability of DAPI counts and the count of fungi isolated from the littoral water. Probe-specific cell counts are presented as a percentage of cells visualized by DAPI, and the mean abundances and SDs were calculated using Statistica v.9 software (Statistic Graphic 2010). The impact of hydrochemical parameters on the studied microbiological parameters in the analyzed water samples was determined with canonical correspondence analysis (CCA). The ordination was performed using CANOCO 4.5 Wageningen UR, Netherlands (ter Braak and Šmilauer 2002).

\section{Results}

Hydrochemical Analyses

Table 2 lists the results of hydrochemical analyses. Water from the littoral zones in all research seasons was 
Table 2 Mean values of selected physicochemical water parameters (T, pH, DO) and the share of DDT ( $\Sigma$ DDT) and its metabolites DDE, DDD, and DDT in water of selected sites in 2008-2010

\begin{tabular}{|c|c|c|c|c|c|c|c|c|c|c|c|c|}
\hline \multirow[t]{3}{*}{ Parameter season } & \multicolumn{8}{|c|}{ Szeląg Wielki Lake } & \multirow{2}{*}{\multicolumn{4}{|c|}{$\frac{\text { Ruda Woda Lake }}{\text { Lit-control }}$}} \\
\hline & \multicolumn{4}{|c|}{ Lit-1 exposed site } & \multicolumn{4}{|c|}{ Lit-2 unexposed site } & & & & \\
\hline & $\begin{array}{l}\mathrm{T} \\
\left({ }^{\circ} \mathrm{C}\right)\end{array}$ & $\begin{array}{l}\text { DO } \\
\left(\mathrm{ugl}^{-1}\right)\end{array}$ & $\mathrm{pH}$ & $\begin{array}{l}\sum \text { DDT } \\
\left(\mathrm{mgl}^{-1}\right)\end{array}$ & $\begin{array}{l}\mathrm{T} \\
\left({ }^{\circ} \mathrm{C}\right)\end{array}$ & $\begin{array}{l}\mathrm{DO} \\
\left(\mathrm{ugl}^{-1}\right)\end{array}$ & $\mathrm{pH}$ & $\begin{array}{l}\Sigma \mathrm{DDT} \\
\left(\mathrm{mgl}^{-1}\right)\end{array}$ & $\begin{array}{l}\mathrm{T} \\
\left({ }^{\circ} \mathrm{C}\right)\end{array}$ & $\begin{array}{l}\text { DO } \\
\left(\mathrm{ugl}^{-1}\right)\end{array}$ & $\mathrm{pH}$ & $\begin{array}{l}\sum \text { DDT } \\
\left(\mathrm{mgl}^{-1}\right)\end{array}$ \\
\hline Early spring & 8.4 & 9.6 & 7.9 & 194 & 8.3 & 10.7 & 7.8 & 0 & 8.5 & 9.5 & 7.9 & 0 \\
\hline Late spring & 15.2 & 13.0 & 8.1 & 175 & 14.4 & 12.6 & 8.5 & 0 & 16.5 & 11.9 & 8.5 & 0 \\
\hline Summer & 23.9 & 10.9 & 8.5 & 125 & 23.9 & 10.6 & 8.2 & 0 & 26.3 & 8.5 & 8.3 & 0 \\
\hline Autumn & 17.0 & 9.9 & 8.5 & 26 & 18.0 & 9.9 & 8.0 & 0 & 19.0 & 8.9 & 8.2 & 0 \\
\hline
\end{tabular}

$T$ temperature, $D O$ dissolved oxygen

characterized by good oxygenation and quite high average annual temperature, which did not decrease below $8{ }^{\circ} \mathrm{C}$. The content of DDT $\left(\mathrm{mg} \mathrm{L}^{-1}\right)$ in water was analyzed for all sites. Its presence was observed only at the Lit-1 exposed site. The quantity of DDT detected tended to decrease from early spring to autumn throughout the entire 3 -year period of research. Table 3 lists the mean values of this parameter. The hydrochemical variables used in the ordination explain $69.8 \%$ of the total variation of microbiological parameters. Reaction $(\mathrm{pH})$ and temperature were statistically important factors that determined the variation of microbiological parameters (Fig. 1).

\section{Total Bacterial and Fungal Abundance}

Seasonal analysis concerning the abundance of bacteria from littoral zones of lakes proved that, on average, $10 \times 10^{6} \mathrm{~mL}^{-1}$ microorganisms were observed at the turn of summer and autumn (Fig. 2). In that period, only slight differences were observed for individual sites. The highest value for a total bacteria count in the littoral zone of Lake Szelạg Wielki, reached by the small water course flowing from the area reclaimed after the pesticide dump (Lit-1 exposed site), was observed in summer; however, almost 2 months later the highest bacterial abundance was found on the opposite shore of the lake (Lit-2 unexposed site). The average bacterial count in spring for all sites did not exceed $8 \times 10^{6} \mathrm{~mL}^{-1}$.

A tendency for seasonal changes in the total count of fungi was also found. Fungi were most abundant in the summer and autumn (Fig. 3). The exception was the Lit-1 exposed site, where fungi were found only in early spring and summer. On the other side of Lake Szeląg Wielki (Lit-2 unexposed site), fungi were isolated from water samples for the entire research period, with highest number in autumn (66 colony-forming units [CFU] $\left.\mathrm{mL}^{-1}\right)$.

\section{Bacterial and Fungal Composition in the Littoral Zone}

Eubacteria identified in the water of the littoral zone accounted for $51 \%$ to $90 \%$ of total bacterial abundance (TBA) detected by DAPI (TBA-DAPI) staining (Fig. 4a). For the great part of the research period, $>65 \%$ Eubacteria were identified. The group of microorganisms with the most abundant representation was Actinobacteria in the control lake; their share decreased from early spring to summer (40\% on average in relation to TBA-DAPI) to reach a value that was almost half as high in autumn $(20 \%$ on average). In Lake Szelagg Wielki, the same pattern of seasonal changes was observed in two littoral sites, with a slight predominance in the Lit-2 unexposed site (Fig. 4a). A similar tendency was found for Betaproteobacteria, which formed the second-largest group of microorganisms in terms of abundance determined in the littoral zones of the examined lakes (Fig. 4b). Within this group, the share of bacteria of Alcaligenes spp. was analyzed. Seasonal dynamics results for bacteria identified with the ALBO 557 probe in relation to TBA-DAPI are presented in Fig. $4 \mathrm{~b}$. Bacteria of the Alcaligenes genus in the control lake formed an even share (20\% to $30 \%$ ) within Betaproteobacteria for the entire period of research. In Lake Szeląg Wielki, their share in the spring period was greater, amounting to $30 \%$ in the Lit-1 exposed site and $46 \%$ in the Lit-2 unexposed site regarding all Betaproteobacteria. During the second half of the year, the bacterial abundance, as detected by BET42a probe, significantly decreased with, on average, $15 \%$ and $10 \%$ in the Lit-1 and Lit 2 exposed sites, respectively.

Gammaproteobacteria were represented in the community of microorganisms in large quantities. At the Lit-1 exposed site, they were more abundant for the entire research period than at the Lit-2 unexposed and the Lit-control sites (Fig. 4c). Regarding Gammaproteobacteria, particular attention was given to the Pseudomonas genus, which was most abundantly recorded in summer 
Table 3 Species composition of fungi isolated from the water of lakes Szeląg Wielki and Ruda Woda

\begin{tabular}{|c|c|c|c|}
\hline \multirow[t]{2}{*}{ Season } & \multicolumn{2}{|l|}{ Szeląg Wielki } & \multirow{2}{*}{$\begin{array}{l}\text { Ruda Woda } \\
\text { Lit-control }\end{array}$} \\
\hline & Lit-1 exposed site & Lit-2 unexposed site & \\
\hline Early spring & A. fumigatus & A. fumigatus & $\begin{array}{l}\text { A. fumigatus } \\
\text { Trichoderma citrinoviridae }\end{array}$ \\
\hline Late Spring & A. fumigatus & A. fumigatus Lipomyces & $\begin{array}{l}\text { A. fumigatus } \\
\text { T. citrinoviridae }\end{array}$ \\
\hline Summer & A. fumigatus & $\begin{array}{l}\text { A. fumigatus } \\
\text { Exophiala dermatitidis } \\
\text { Pichia anomala }\end{array}$ & $\begin{array}{l}\text { A. fumigatus } \\
\text { A. viridis } \\
\text { Candida glabrata } \\
\text { Debaryomyces vannrijae } \\
\text { E. spinifera } \\
\text { Oosporidium margaritiferum } \\
\text { T. citrinoviridae } \\
\text { T. viride }\end{array}$ \\
\hline Autumn & A. fumigatus & $\begin{array}{l}\text { P. guilliermondii } \\
\text { (C. guilliermondii) } \\
\text { Rhizopus sp. }\end{array}$ & $\begin{array}{l}\text { Kluyveromyces marxianus } \\
\text { K. polysporum } \\
\text { Rhodotorula glutinis, Exophiala spinifera, } \\
\text { T. citrinoviridae } \\
\text { Trichosporon inkin }\end{array}$ \\
\hline
\end{tabular}

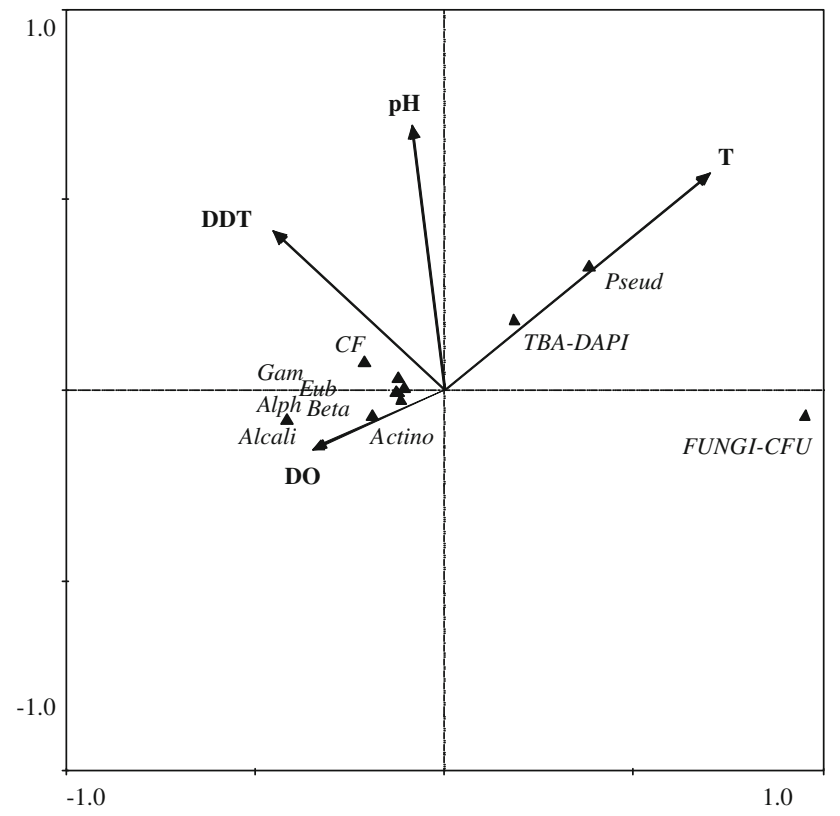

Fig. 1 Results of CCA between hydrochemical variables (pH, DDT, temperature $[\mathrm{T}]$, dissolved oxygen [DO]) and microbiological parameters in littoral zones. FUNGI-CFU = total number of fungi abundances; Eub Eubacteria, Alph Alphaproteobacteria, Beta Betaproteobacteria, Gam Gammaproteobacteria, Actino Actinobacteria, CF Cytophaga-Flavobacterium, Alcali Alcaligenes spp., Pseud Pseudomonas spp

(5.5\% on average for Lake Szeląg Wielki and $6.5 \%$ for Lake Ruda Woda relative to all TBA-DAPI bacteria) despite the fact that the count of Gammaproteobacteria in that season was the lowest for the entire period of research.

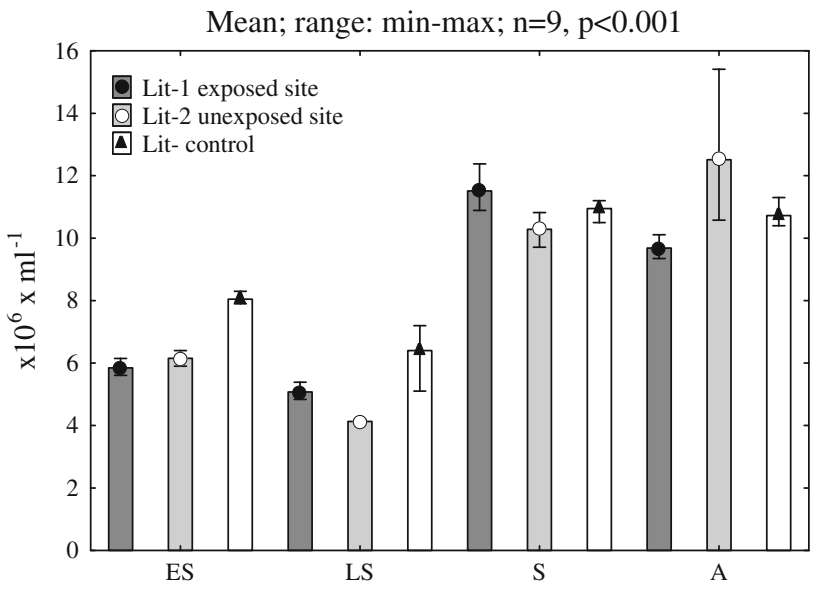

Fig. 2 Seasonal change (ES early spring, $L S$ late spring, $S$ summer, $A$ autumn) of total number of bacteria abundances (TBA-DAPI) in littoral zones of Lake Szeląg Wielki (black circle $=$ Lit-1 exposed site; white circle $=$ Lit-2 unexposed site) and Lake Ruda Woda (black triangle $=$ Lit-control)

The two other groups of microorganisms of the Eubacteria type (Alphaproteobacteria and Cytophaga-Flavobacterium) were recorded in the lowest quantities, whereas the pattern of seasonal changes showed a similarity between sites situated on Lake Szeląg Wielki and a slight departure for the control site (Fig. 4d). However, both groups were most abundantly represented during the entire season in late spring, and at all sites their count was the lowest in the summer. 


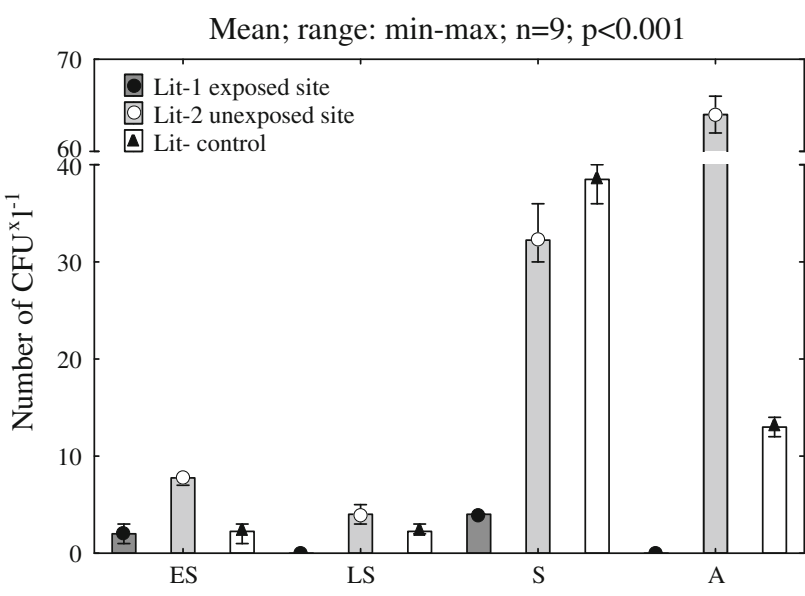

Fig. 3 Seasonal change change (ES early spring, $L S$ late spring, $S$ summer, $A$ autumn) of total number of fungi abundances (CFU) in the littoral zones of Lake Szeląg Wielki (black circle $=$ Lit-1 exposed site; white circle $=$ Lit-2 unexposed site) and Lake Ruda Woda (black triangle $=$ Lit-control)

Fungi were regularly observed for the entire research period at the Lit-2 unexposed and Lit-control sites. At the Lit-1 site, where the watercourse carried rainwater from the area reclaimed after the pesticide tomb, fungi appeared in scarce quantities both in very early spring and in the summer. However, at the Lit-2 unexposed site on the same lake, not only were fungi recorded in all research seasons, but they also occurred in the greatest quantities among all sites under analysis, particularly during the period of summer to autumn (Fig. 3).

Seventeen species of fungi were isolated from all sites: 12 mold and 5 yeast-like. The dominating species throughout the entire research period was Aspergillus fumigatus. In late spring, it was present at all sites. The greatest variety of isolated species of fungi was observed in the littoral zone of Lake Ruda Woda, and the lowest was in the Lit-1 exposed site of Lake Szelag Wielki (Table 3).

\section{Discussion}

The acquisition of data concerning the biodiversity and distribution of various groups of bacteria in water bodies forms an important part of each ecological-monitoring process (Drucker and Panasyuk 2006). This information is important because microorganisms respond with changes in both their numbers and community composition to shortterm disruptions of ecosystem balance as well as to a longterm supply of allochtonic substances. This response also applies to the environment polluted with toxic substances, such as POPs (Lew et al. 2011). In such ecosystems, microorganisms play a particularly important role, showing the ability to accumulate, detoxify, and metabolize compounds that are toxic for the environment. They often use such compounds as a source of carbon (DeLorenzo et al. 2001). In contrast, the presence of selected toxic substances, such as pesticides, can be a factor limiting the occurrence of some bacteria and fungi, which is also an indicator of ecosystem condition.

In this study, observations of seasonal dynamics patterns concerning the abundance of microorganisms showed a similarity for all sites. Spring thaw and surface runoffs, carrying organic matter from the environment, resulted in a slight increase in bacterial count at all sites, with the highest values recorded in summer and autumn. This finding is a characteristic feature of eutrophic lakes (Lew et al. 2011). Favorable thermal-aerobic conditions and an increased amount of quite easily assimilable nutritional substrates affect the processes of intensive microbiological degradation. This in turn drove the quick growth of bacterial populations (Ploug and Grossart 2000; Grossart and Ploug 2001) that we observed in our research. In addition, macrophytes provide a source of increased supply of organic matter in the littoral zone (Kominkova et al. 2000; Wu et al. 2010, Obolewski et al. 2011). The presence of water plants is positively correlated with the amount and the biomass of microorganisms, which also affects their biodiversity (Wu et al. 2010; $\mathrm{Ng}$ et al. 2010). It has been reported that on the reed Phragmites australis alone, $>600$ species of fungi can be isolated (Gessner and van Ryckegem 2003; Wu et al. 2010). This species was the main macrophyte component of the littoral zones at the sites we examined (Grzybowski et al. 2005).

The research indicated that despite the presence of DDT and its traces in the water at the Lit-1 exposed site, there was no modifying effect on the bacteria count. However, the presence of this pesticide in water could have been a factor limiting the presence of fungi. A significant decrease in fungal species diversity was observed for this site. DDTinduced changes in the species diversity index for fungi living in soil and in water have already been reported (Boyer and Perry 1973). In our research, A. fumigatus was the most often identified fungal species. It is a saprophyte fungus that plays a key environmental role in carbon and nitrogen circulation (Haines 1995; Latge 1999). In natural ecological niches, the survival and growth of this species is determined by organic remains, large amounts of which are observed in each littoral type in the form of dead macrophyte material and deposited allochtonic waste, such as leaves, wood, twigs, dead animals, insects, and seeds (Czeczuga et al. 2002, 2005; Nechwatal et al. 2008; Wu et al. 2010). However, at the site where DDT was observed in water, A. fumigatus was the only isolated representative of fungal taxa. Studies have shown the ability of fungi to biodegrade pesticides in the water environment. Mineralization is performed by ligninolytic fungi, particularly white 
Fig. 4 a-d Seasonal change change ( $E S$ early spring, $L S$ late spring, $S$ summer, $A$ autumn) of taxonomic composition of the bacterial communities in the littoral zones of Lake Szeląg Wielki (black circle $=$ Lit-1 exposed site; white circle $=$ Lit-2 unexposed site) and Lake Ruda Woda (black triangle $=$ Lit-control). Values are expressed as the percentage of hybridized cell counts of TBA of DAPI-stained cells. $* p<0.001 ; * * p<0.05$
A

Eubacteria

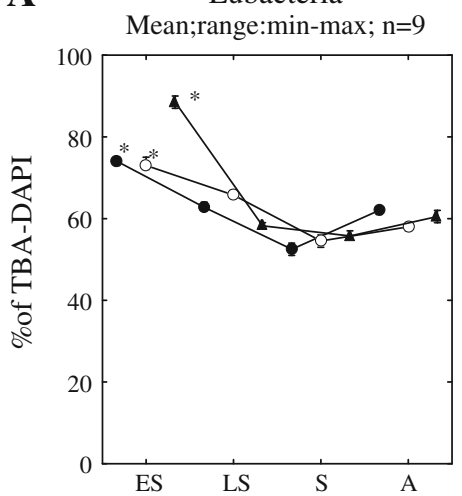

B

Beta-proteobacteria Mean;range:min-max; $n=9$

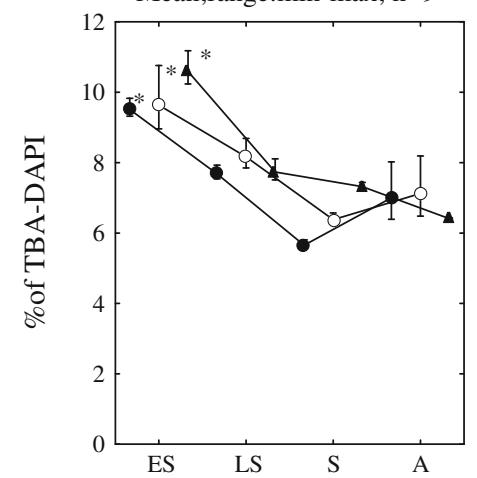

C

Gamma-proteobacteria Mean;range:min-max; $n=9$

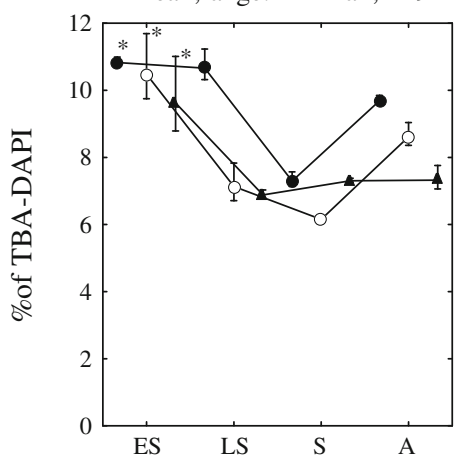

D

Alpha-proteobacteria Mean;range:min-max; $n=9$

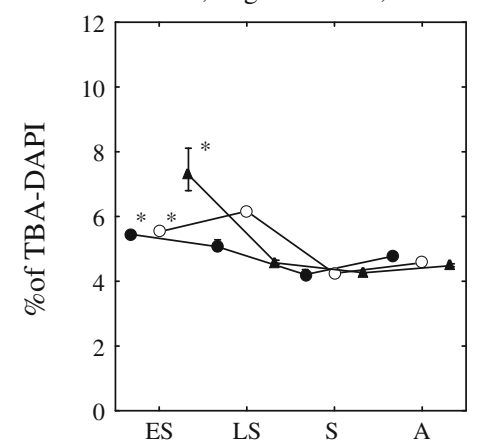

Actinobacteria

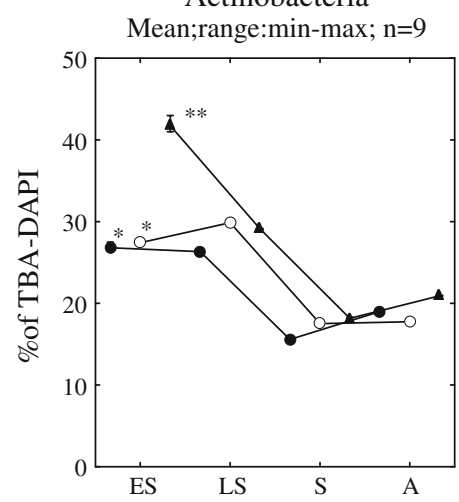

Alcaligenes spp.

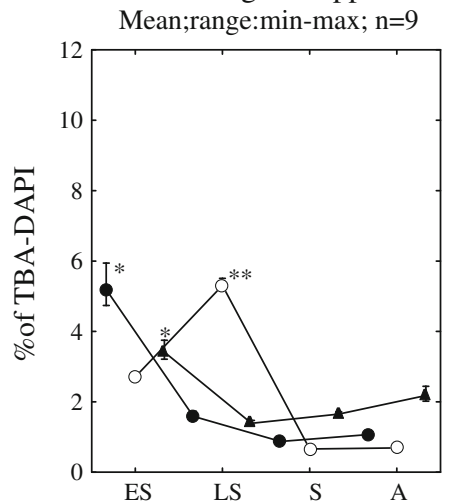

Pseudomonas spp.

Mean;range:min-max; $n=9$

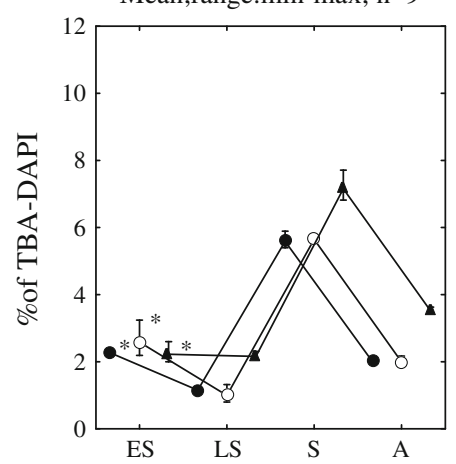

Cytophaga-Flavobacterium Mean;range:min-max; $n=9$

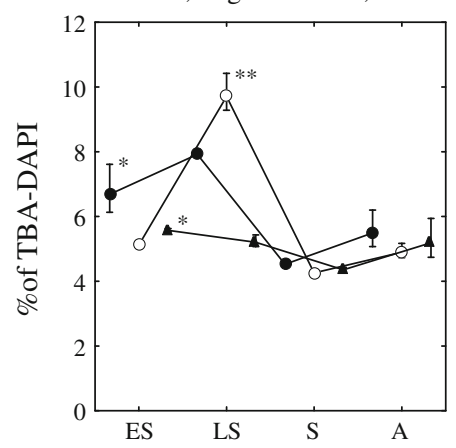


rot fungi (Aislabie et al. 1997; Jauregui et al. 2003; Thomas and Gohil 2010). In contrast, no reports concerning any metabolic predisposition of A. fumigatus for DDT decomposition in water are available; therefore, its presence at this site could be attributed to an outstanding ability to adapt to each environment resulting from its uncomplicated spreading mechanism and, consequently, fast colonization of the ecosystem (Latge 1999; Wu et al. 2010). The seasonal differences in the size and structure of fungal community in the control lake may be caused by the inflow of biogenes into the reservoir. After the spring melt and the inflow of substances that form the nutritional basis, an increase in number and diversification of fungal species is observed in eutrophic lakes (Dynowska et al. 2001; Luo et al. 2004). Our studies have confirmed this relationship. The highest number and most diverse profile of species in Lake Ruda Woda were reported in summer and observed until autumn.

In this study, we examined whether any long-lasting effect of the pesticide tomb was identifiable in terms of the diversity of microorganisms of the Eubacteria domain. With this aim in view, we analyzed a pattern of seasonal changes to bacterioplankton using FISH (Pernthaler et al. 2001a, b; Fazi et al. 2005; Souza et al. 2007; Gerbersdorf et al. 2009; Lew et al. 2011). By this method, including use of the HGC 69a probe, we observed the dynamics of Actinobacteria. This was the group that, in our research, made up the greatest share of microorganisms in all seasons, with particularly high abundance in the spring period. Actinobacteria are commonly found in soil, where they decompose organic compounds and play an important role in mineralization. However, they also inhabit water systems (particularly in places with an inflow of allochtonic organic matter), and their abundance in an ecosystem marking a transitory zone between those two environments is to be expected (Rheims et al. 1999). As research has shown, this group is one of the most numerous in lakes, sometimes accounting for approximately half of all microorganisms identified in inland waters (Burket et al. 2003; Van der Gucht et al. 2005; Allgaier and Grossart (2006). Our observations confirm these reports: In the control lake, Lake Ruda Woda, the share of this group reached $40 \%$ in summer in relation to TBC-DAPI. Slightly lower values were observed in Lake Szeląg Wielki, particularly at the site where the presence of DDT was detected. These bacteria, particularly Streptomyces and Micromonospora, can grow in the presence of chloroorganic pesticides (Benimeli et al. 2003, 2006, 2007; Cuozzo et al. 2009). Experimental studies have shown that in an environment that has not been previously polluted with pesticides, bacteria and actinomycetes are DDT sensitive; however, in a polluted environment many of these microorganisms are not affected or even stimulated by this pesticide. Some investigators have suggested that some Actinobacteria show adaptive abilities to survive in an environment polluted with DDT (Benimeli et al. 2003), which is also supported by our findings from the Lit-1 exposed site.

In our research, we also paid particular attention to two other groups of microorganisms predisposed to mineralize compounds that are difficult to decompose in the environment: Alcaligenes spp. of the Beta subclass of Proteobacteria and Pseudomonas spp. of the Gamma-subclass of Proteobacteria. Nadeau et al. $(1994,1998)$ and Parsons (1995) observed that the biphenyl-degrading enzymes of Alcaligenes spp. could attack, in a broad scope, aromatic compounds and prove useful in DDT degradation. We also observed a large representation of this group of bacteria in the bacterioplankton, with particular focus on the site where DDT was detected. Here, the participation of Alcaligenes within Betaproteobacteria was slightly greater than at other sites and did not decrease below $15 \%$ of all Betaproteobacteria. The presence of chloro-organic pesticides in the water of this littoral zone was confirmed by the low sensitivity of this bacterial group to pollutants reaching the environment (Gonzales et al. 1998). However, Betasubclass of Proteobacteria is a dominating fraction of freshwater microorganisms, particularly in the pelagial zones (Pernthaler et al. 1998; Klammer et al. 2002; Pesce et al. 2006; Lew et al. 2011).

Gammaproteobacteria do not make a numerous group in the lake bacterioplankton. Most often, they form a community of microorganisms living in the river biofilm or detritus (Kirchman 2002). The share of this group of proteobacteria in the community of littoral microorganisms at a level of approximately $6 \%$ to $11 \%$ in relation to all identified microorganisms brings these data closer to the results obtained in analyses of marine coastal waters (Cottrell and Kirchman 2000a, 2000b). Regarding the Gamma subclass of Proteobacteria, emphasis was placed on Pseudomonas spp. As shown by previous research, this group of microorganisms can participate in biodegradation of herbicides and chloro-organic pesticides (Nawab et al. 2003; Kamanavelli and Ninnekar 2000, 2004; Koneva 2004; Li-feng et al. 2007). In the natural environment, under aerobic conditions, Pseudomonas spp. can degrade chloro-organic compounds, including DDT, to 4-chlorobenzoic acid. Previous studies have indicated that it is from ecosystems polluted with insecticides that these microorganisms can be successfully isolated on culture media enriched with biphenyl (Kamanavelli and Ninnekar 2004). In our research, the share of Pseudomonas spp. was also observed in the community of plankton microorganisms of littoral zones. Nevertheless, it was not proven that the presence of DDT observed at the Lit-1 exposed site could have in any way affected their share in the community of 
microorganisms. A clear increase in summer, also in the form of compounds that are difficult to decompose but that Pseudomonas bacteria specialize in metabolizing, confirmed the presence only of organic matter in water during that period.

Cytophaga-Flavobacterium phylotypes are chemoorganotrophs whose basic function in water ecosystems is dissolved organic matter uptake and degradation. They decompose biopolymers, such as cellulose and chitin-i.e., the high molecular-mass fraction-that are a part of the dissolved organic matter (Kirchman 2002). The high molecular mass of the dissolved organic matter fraction is most intensively released from aggregates and detritus during spring water circulation and after the matter reaches the reservoir with surface runoff. The second period in which the lakes are enriched with this type of matter is autumn decomposition of macrolytes (Manz et al. 1996; Kirchman 2002). The Cytophaga-Flavobacterium group in our studies was characterized by a larger share throughout the entire research period in spring and by a slightly lower, but also recorded, growth of this group in autumn. No effect of the pesticide presence was observed on the seasonal dynamics of these microorganisms.

The presence of pesticides in water inevitably affects inhabitants of these ecosystems. Unfortunately, the harmful influence of pesticides on microbial species subsequently affects organisms at greater trophic levels (DeLorenzo et al. 2001; Friberg-Jansen et al. 2003). A littoral zone, acting as a buffer protecting lakes against external pollution, is where many substances reaching the reservoir from the environment collect. Microorganisms inhabiting this area respond to the presence of pesticides washed out from the drainage area. They participate in the decomposition of harmful substances, thus contributing to detoxification of the environment they inhabit. Long-term exposure to the presence of pesticides can stimulate adaptive abilities in many microorganisms and contribute to participation of those substances in metabolic transformations. In addition, bacteria and fungi, because of quick changes in quality and quantity composition of the community, provide a convenient indicator of the status of the ecosystem they inhabit and can be used for its monitoring. Our environmental research confirmed those assumptions, which have thus far been verified only through laboratory experiments. The quantity dynamics of bacterioplankton showed here a pattern that is characteristic for eutrophic water reservoirs-the lack of response of the littoral community to the presence of pesticides-and confirms bacterial adaptation to seasonal exposure to DDT. In addition, slight changes in the percentage share of individual large groups of bacteria can indicate changes in the environment and suggest the need to monitor such ecosystems. Nevertheless, they unquestionably indicate a high flexibility of the water environment and adaptive abilities of microorganisms as well as their participation in the struggle for preserving the balance of the ecosystem they inhabit.

Determination of the share of Alcaligenes spp. in the community proved more useful than determination of the share of Pseudomonas spp. as an indicator of changes within the bacterioplankton caused by the DDT presence in water. Experimental data were confirmed, showing on one hand a high susceptibility of selected fungal species to toxic substances and proving in contrast that a long-lasting inflow of harmful substances results in a decrease in fungal species diversity.

Acknowledgments This study was supported by a grant within scientific investigation project in 2008-2011 (Grant No. N N305 232435)

Open Access This article is distributed under the terms of the Creative Commons Attribution License which permits any use, distribution, and reproduction in any medium, provided the original author(s) and the source are credited.

\section{References}

Aislabie JM, Richards NK, Boul HL (1997) Microbial degradation of DDT and its residues-A review. N Z J Agric Res 40:269282

Allgaier M, Grossart H-P (2006) Diversity and seasonal dynamics of Actinobacteria populations in four lakes in northeastern Germany. Appl Environ Microbiol 72:3489-3497

Amarowicz R, Smoczyński SS, Borejszo Z (1986) Szybka metoda wyodrębnienia chlorowanych węglowodorów z tłuszczu [in Polish]. Roczn PZH 37:542-562

Benimeli CS, Amoroso MJ, Chaile AP, Castro GR (2003) Isolation of four aquatic streptomycetes strains capable of growth on organochlorine pesticides. Bioresour Technol 89:133-138

Benimeli CS, Castro GR, Chaile AP, Amoroso MJ (2006) Lindane removal induction by Streptomyces sp M7. J Basic Microbiol 46:348-357

Benimeli CS, Castro GR, Chaile AP, Amoroso MJ (2007) Lindane uptake and degradation by aquatic Streptomyces sp strain M7. Int Biodeter Biodegradation 59:148-155

Biedunkiewicz A, Baranowska E (2011) Yeasts and yeast-like fungi as an element of purity assessment of surface waters. Pol J Environ Stud 20:267-274

Biedunkiewicz-Ziomek A, Dynowska M (2004) Candida dubliniensis new species in the human respiratory system. Acta Mycol 39:7-12

Boyer MG, Perry E (1973) Diversity in soil fungi as influence by DDT. Mycopathol Mycol Appl 49:255-262

Buesing N, Gesser MO (2006) Benthic bacterial and fungal productivity and carbon turnover in a freshwater marsh. Appl Environ Microbiol 72:596-605

Burkert U, Warnecke F, Babenzien D, Zwirnmann E, Pernthaler J (2003) Members of readily enriched B-Proteobacterial clade are common in surface waters of a humic lake. Aquat Microb Ecol 69:6550-6559

Carabias-Martinez R, Rodriguez-Gonzalo E, Fernández-Laespada ME, Calvo-Seronero L, Sánchez-San Roman FJ (2003) Evolution over time of the agricultural pollution of waters in an areas of Salamanca and Zamora (Spain). Water Res 37:928-938 
Cerejeira MJ, Viana P, Batista S, Pereira T, Silva E, Valerio MJ et al (2003) Pesticides in Portuguese surface and ground waters. Water Res 37:1055-1063

Cottrell MT, Kirchman DL (2000a) Community composition of marine bacterioplankton determined by $16 \mathrm{~S}$ rDNA clone libraries and fluorescence in situ hybridization. Appl Environ Microbiol 66:5116-5122

Cottrell MT, Kirchman DL (2000b) Natural assemblages of marine proteobacteria and members of the Cytophaga-Flavobacter cluster consuming low- and high- molecular-weight dissolved organic matter. Appl Environ Microbiol 66:1692-1697

Cuozzo SA, Rollán GG, Abate CM, Amoroso MJ (2009) Specific dechlorinase activity in lindane degradation by Streptomyces $\mathrm{sp}$ M7. World J Microbiol Biotechnol 25:1539-1546

Czeczuga B, Kozlowska M, Godlewska A (2002) Zoosporic aquatic fungi growing on dead specimens of 29 freshwater crustacean species. Limnologica 32:180-193

Czeczuga B, Mazalska B, Godlewska A, Muszynska E (2005) Aquatic fungi growing on dead fragments of submerged plants. Limnologica 35:283-297

Daims H, Bruhl A, Amann R, Schleifer K-H, Wagner M (1999) The domain-specific probe EUB 338 is insufficient for the detection of all bacteria: development and evaluation of a more comprehensive probe set. Syst Appl Microbiol 22:434-444

De Hoog S, Guarro J, Gene J, Figureas MJ (2000) Atlas of clinical fungi. Universitet Rovira i Virgia, Reus, p 1126

DeLorenzo ME, Scott GI, Ross PE (2001) Toxicity of pesticides to aquatic microorganisms: a review. Environ Toxicol Chem 20:84-98

Drucker VV, Panasyuk EY (2006) Potentially pathogenic bacteria in a microbial community of Lake Baikal. Hydrobiologia 568: 267-271

Dynowska M, Biedunkiewicz A, Ejdys E (2001) Pathogenic yeastlike fungi with bio-indicator properties. Pol J Environ Stud 10: $13-16$

Ellis MB, Ellis JP (1985) Microfungi on land plants: An identification handbook $\left(1^{\text {st }}\right.$ ed). Macmillan, New York

Fazi S, Amalfitano S, Pernthaler J, Puddu A (2005) Bacterial communities associated with benthic organic matter in headwater stream microhabitats. Environ Microbiol 7:1633-1640

Fleeger JW, Carman KR, Nisbet RM (2003) Indirect effect of contaminants in aquatic ecosystems. Sci Total Environ 317: 207-233

Foit A, Chatzinotas M, Liess K (2010) Short-term disturbance of a grazer has long-term effects on bacterial communities-Relevance of trophic interactions for recovery from pesticide effects. Aquat Toxicol 99:205-211

Friberg-Jansen U, Wendt-Rasch L, Woin P, Christoffersen K (2003) Pyrethroid insecticide, cypermethrin, on a freshwater community studied under field conditions. I. Direct and indirect effects on abundance measures of organisms at different trophic levels. Aquat Toxicol 63:357-371

Gerbersdorf SU, Bittner R, Lubarsky H, Manz W, Peterson DM (2009) Microbial assemblages as ecosystem engineers of sediment stability. J Soil Sed 9:640-652

Gerlach D (1972) Zarys mikrotechniki botanicznej [in Polish]. PWRLiE, Warszawa, p 267

Gessner MO, Van Ryckegem G (2003) Water fungi as decomposers in freshwater ecosystems. In: Bitton G (ed) Encyclopaedia of environmental microbiology. Wiley, New York, pp 1-38

Glinska-Lewczuk K, Skwierawski A, Kobus S, Sidoruk M, Krzyżaniak M (2009) Spatial distribution of heavy metals in bottom sediments of oxbow lakes in northern Poland differed by hydrological connectivity. Fresnius Environ Bull 7:11381145

Gonzáles B, Clément P, Céspedes R, Valenzuela J, Matus V, Maturana A et al (1998) Degradation of environmental pollutants by Alcaligenes eutrophus JMP143 (pJP4). Environ Toxicol Water Qual 11:205-211

Grossart HP, Ploug H (2001) Microbial degradation of organic carbon and nitrogen on diatoms aggregates. Limnol Oceanogr 46: 267277

Grzybowski M, Szarek J, Skibniewska KA, Sawicka-Kapusta K, Guziur J, Endler Z (2005) The characteristics of plants in the littoral zone of Lake Szaląg Wielki in the Iława Lake District threatened by pesticide tomb. Fresenius Environ Bull 14: 357362

Haines J (1995) Aspergillus in compost: straw man or fatal flaw. Biocycle 6:32-35

Hildenbrandt A, Guillamon M, Lacore S, Tauler R, Barcelo D (2008) Impact of pesticides used in agriculture and vineyards to surface and groundwater quality (North Spain). Water Res 42:3315-3326

Howard DH (2003) Pathogenic fungi in humans and animals. Marcel Dekker, New York, p 790

Jauregui J, Valderrama B, Albores A, Vazquez-Duhalt R (2003) Microsomal transformation of organophosphorus pesticides by white rot fungi. Biodegradation 14:397-406

Kalwasińska A, Kęsy J, Wik I, Donderski W (2010) Neustonic versus epiphytic bacteria of eutrophic Lake and their biodegradation ability on deltamethrin. Biodegradation 22:699

Kamanavalli CM, Ninnekar HZ (2000) Biodegradation of propoxur by Pseudomonas species. World J Microbial Technol 16:329-331

Kamanavalli CM, Ninnekar HZ (2004) Biodegradation of DDT by Pseudomonas species. Curr Microbiol 48:10-13

Kirchman D (2002) The ecology of Cytophaga-Flavobacteria in aquatic environments. FEMS Microbiol Ecol 39:91-100

Klammer S, Posch T, Sonntag B, Griebler C, Mindl B, Psenner R (2002) Dynamic of bacterial abundance, biomass, activity, and community composition in the oligotrophic traunsee and the Traun River (Austria). Water Air Soil Pollut 2:137-163

Kominkova D, Kuehn KA, Büsing N, Steiner D, Gessner MO (2000) Microbial biomass, growth, and respiration associated with submerged litter of Phragmites australis decomposing in a littoral reed stand of a large lake. Aquat Microbiol Ecol 22:271-282

Koneva ND (2004) Characterization and in situ monitoring of atrazine-transforming bacteria. Microbiology 73:654-657

Konstantinou IK, Hela DG, Albanis TA (2006) The status of pesticide pollution in surface waters (rivers and lakes) of Greece. Part I. Review on occurrence and levels. Environ Pollut 141:555-570

Kurtzmann CP, Fell JW (2000) The yeasts: A taxonomic study (4th ed). Elsevier Amsterdam, Netherlands, p 1055

Latgé JP (1999) Aspergillus fumigatus and aspergillosis. Clin Microbiol Rev 12:310-350

Leboulanger C, Bouvy M, CarréCecchi P, Amalric L, Bouchez A, Pagano $M$ et al (2011) Comparsion of the effects of two herbicides and an insecticide on tropical freshwater plankton in microcosms. Arch Environ Contam Toxicol 61:599-613

Lew S, Lew M, Szarek J, Babińska I (2011) Seasonal patterns of the bacterioplankton community composition in a lake threatened by a pesticide disposal site. Environ Sci Pollut Res 18:376-385

Li-feng G, Jian-dong J, Xiao-hui L, Ali SW, Shun-peng L (2007) Biodegradation of ethametsulfuron-Metthyl by Pseudomonas $\mathrm{sp}$ SW4 isolated from contaminated soil. Curr Microbiol 55:420-426

Lodder J, Kreger-van Rij NJW (1967) The yeasts. A taxonomic study. North-Holland Publishing Company, Amsterdam, p 713

Ludwicki JK, Góralczyk K, Czaja K, Struciński P (1996) Oznaczanie pozostałości insektycydów chloroorganicznych i polichlorowanych bifenyli w środkach spożywczych metodą chromatografii gazowej [in Polish]. Wydawnictwo Metodyczne PZH, Warszawa

Luo J, Yin JF, Cai L, Zhang KQ, Hyde KD (2004) Freshwater fungi in Lake Dianchi, a heavily polluted lake in Yunnan, China. Fungal Divers 16:93-112 
Manadori L, Gambaro A, Piazza R, Ferrari S, Stortini AM, Capotaglio G (2006) PCBs and PAHs in a sea-surface microlayer and sub-surface water samples of the Venice Lagoon (Italy). Mar Pollut Bull 52:184-192

Manz W, Amann R, Ludwig W, Wagner M, Schleifer KH (1992) Phylogenetic Oligodeoxynucleotide probes for the major subclasses of proteobacteria: problems and solutions. Syst Appl Microbiol 15:593-600

Manz W, Amann R, Ludwig W, Vancanneyt M, Schleifer KH (1996) Application of a suite of $16 \mathrm{~S}$ rRNA-specicc oligonucleotide probes designed to investigate bacteria of the phylum CytophagaFlavobacter-Bacteroides in the natural environment. Microbiology 142:1097-1106

Midgley G, Hay RJ, Clayton YM (1997) Mikologia lekarska. Kompendium i atlas [in Polish]. CZELEJ, Lublin, p 155

Nadeau L, Menn FM, Breen A, Sayler GS (1994) Aerobic degradation of 1,1,1-trichloro-2,2-bis(4-chlorophenyl)ethane (DDT) by Alcaligenes eutrophus A5. Appl Environ Microbiol 60:51-55

Nadeau LJ, Sayer GS, Spain JC (1998) Oxidation of 1,1,1-trichloro2,2-bis(4-chlorophenyl)ethane (DDT) by Alcaligenes eutrophus A5. Arch Microbiol 171:44-49

Nawab A, Aleem A, Malik A (2003) Determination of organochlorine pesticides in agricultural soil with special reference to $\gamma-\mathrm{HCH}$ degradation by Pseudomonas strains. Bioresour Technol 88: $41-46$

Nechwatal J, Wielgoss A, Mendgen K (2008) Diversity, host, and habitat specificity of oomycete communities in declining reed stands (Phragmites australis) of a large freshwater lake. Mycol Res 112:689-696

Ng HT, da Motta Maraques D, Jeppsen E, Søndergaard M (2010) Bacterioplankton in the littoral and pelagial zones of subtropical shallow lakes. Hydrobiologia 646:311-326

Obolewski K, Glińska-Lewczuk K, Kobus SZ (2009) Effect of hydrological connectivity on the molluscan community structure in oxbow lakes of the Łyna River. Oceanol Hydrobiol Stud 4: $75-88$

Obolewski K, Skorbiłowicz E, Skorbiłowicz M, Glińska-Lewczuk K, Astel AM, Strzelczak A (2011) The effect of trace chemical elements accumulated in reed on biofouling in various aquatic ecosystems. Ecotoxicol Environ Safe 74:558-568

Parsons JR (1995) Substrate range of the (chloro)biphenyl degradation pathway of Alcaligenes sp JB1. In: Hinchee RE, Brockman FJ, Vogel CM (eds) Microbial processes for bioremediation, vol 3., Battelle PressColumbus, MO, pp 169-175

Pernthaler J, Glöckner FO, Unterholzner S, Alfreider A, Psenner R, Amann R (1998) Seasonal community and population dynamics of pelagic Bacteria and Archaea in a high mountain lake. Appl Environ Microbiol 64:4299-4306

Pernthaler A, Pernthaler J, Amann R (2001a) Fluorescent in situ hybridization (FISH) with rRNA-targeted oligonucleotide probes (review). Methods Microbiol 30:207-226

Pernthaler A, Pernthaler J, Amann R (2001b) Fluorescent in situ hybridization (FISH) with rRNA-targeted oligonucleotide probes (review). Methods Microbiol 30:207-226
Pesce S, Fajon C, Bardot C, Bonnemoy F, Portelli C, Bohatier J (2006) Effects of the phenylurea herbicide diuron on natural riverine microbial communities in an experimental study. Aquat Toxicol 78:303-314

Pesce S, Fajon C, Bardot C, Bonnemoy F, Portelli Ch, Bohatier J (2008) Longitudinal changes in microbial planktonic communities of a French river in relation to pesticide and nutrient inputs. Aquat Toxicol 86:352-360

Ploug H, Grossard HP (2000) Bacterial growth and grazing on diatom aggregates: respiratory carbon turnover as a function of aggregate size and sinking velocity. Limnol Oceanogr 45:1467-1475

Porter KG, Feig YS (1980) The use of DAPI for identifying and counting aquatic microflora. Limnol Oceanogr 25:943-948

Qureshi AA, Dutka BJ (1976) Comparison of various brands of membrane filters for their ability to recover fungi from water. Appl Environ Microbiol 32:445-447

Raper KB, Fennel DJ (1965) The genus Aspergillus. Williams and Wilkins, Baltimore, p 870

Raper KB, Thom C, Fennel DJ (1949) A manual of the Penicillia. Williams and Wilkins, Baltimore, p 875

Rheims H, Felske A, Seufert S, Stackebrandt E (1999) Molecular monitoring of an uncultured group of the class Actinobacteria in two terrestrial environments. J Microbiol Methods 36:65-75

Roller C, Wagner M, Amann R, Ludwig W, Schleifer KH (1994) In situ probing of Gram-positive bacteria with high DNA G + C content using 23S rRNA-targeted oligonucleotides. Microbiology 140:2849-2858

Singh BK (2009) Organophosphorus-degrading bacteria: ecology and industrial applications. Nat Rev Microbiol 7:156-164

Skibniewska KA (2010) Influence of the pesticide dump on the environment. In: Contemporary problems of management and environmental protection, Olsztyn, p 131

Souza JVB, da Silva Junior RM, Koshikene D, Silva ES (2007) Applications of fluorescent in situ hybridization (FISH) in environmental microbiology. J Food Agric Environ 5:408-411

Ter Braak CJF, Šmilauer P (2002) CANOCO reference manual and user's guide to Canoco for Windows Software for Canonical Community Ordination version 4.5. microcomputer power Ithaca, NY

Thomas JE, Gohil H (2010) Microcosms studies on the degradation of o, p'-DDT. DDE and DDD in a muck soil, World J Microbial Technol 27(3):619-625

Van der Gucht K, Vandekerckhove T, Vloemans N, Cousin S, Muylaert K, Wagner $M$ et al (2003) Fluorescence in situ hybridization for the identification and characterization of prokaryotes. Curr Opin Microbiol 6:302-309

Wu QL, Zwart G, Wu J, Kamst-van Agterveld MP, Liu S, Hahn MW (2010) Submersed macrophytes play a key role in structuring bacterioplanktoncommunity composition in the large shallow, subtropical Taihu Lake, China. Environ Microbiol 9:2765-2774

Zipper Ch, Nickel K, Angst W, Kohler HP (1996) Complete microbial degradation of both enantiomers of the chiral herbicide mecoprop [(RS)-2(chloro-2-methylphenoxy)propionic acid] in an enantioselective manner by Sphingomonas herbicidovorans sp Nov. Appl Environ Microbiol 12:4318-4322 